воспитателей к взаимодействию $\mathrm{c}$ детьми дошкольного возраста в процессе профессиональной подготовки: автореф. дис. на соискание ученой степени канд. пед. наук: спец. 13.00.08 «Теория и методика профессионального образования»/ И. Ф. Слепцова. Москва, 2007. - 24 с. 6. Тодорцева Ю. В. Формування толерантності майбутніх учителів у процесі професійної підготовки: автореф. дис. на здобуття наук. ступеня канд. пед. наук: спец. 13.00.04 «Теорія і методика професійноїосвіти»/ Ю. В. Тодорцева. - Одеса, 2004. $20 \mathrm{c}$.

УДК 37.091.313:[796+811.111]

Людмила Кадченко, Валентина Марчик

\title{
ПРЕДМЕТНА ІНТЕГРАЦІЯ ФІЗКУЛЬТУРИ Й АНГЛІЙСЬКОЇ МОВИ ЯК ЗАСІБ ЗБАГАЧЕННЯ ЗМІСТУ СУЧАСНОГО УРОКУ
}

Кадченко Л. П., Марчик В. І. Предметна інтеграція фізкультури й англійської мови як засіб збагачення змісту сучасного уроку.

Стаття присвячена проблемі інтегрованого підходу в навчанні. Розглядається можливість гармонійного поєднання фізичної культури з іноземною мовою. Обгрунтовується доцільність проведення інтегрованих уроків фізкультури й англійської мови, визначаються шляхи реалізації інтегрованого підходу під час організації спортивно-оздоровчих заходів чи уроків фізкультури іноземною мовою.

Ключові слова: предметна інтеграція, інтегрований підхід, інтегроване навчання, фізкультхвилинка, команда.

Кадченко Л. П., Марчик В. И.Предметная интеграция физкультуры и английского языка как средство обогащения содержания современного урока.

Статья посвящена проблеме интегрированного подхода в обучении. Рассматривается возможность гармоничного сочетания физической культуры с иностранным языком. Обосновывается целесообразность проведения интегрированных уроков физкультуры и английского языка, определяются пути реализации интегрированного подхода при организации спортивно-оздоровительных мероприятий и уроков физкультуры на иностранном языке.

Ключевые слова: предметная интеграция, интегрированный подход, интегрированное обучение, физкультминутка, команда.

Kadchenko L. P., Marchyk V. I. Subject integration of physical education and English as a means of enriching modern lesson content.

The article deals with an integrated approach in teaching. The possibility of a harmonious combination of physical culture and foreign language is examined. The reasonability of conducting the integrated lessons of physical culture and English and the ways of implementation of an integrated approach in the organization of sports activities and physical education lessons in a foreign language are substantiated.

Key words: subject integration, integrated approach, integrated learning, physical activity break, command.

Інтеграція - це вищий рівень реалізації завдань освіти. В освітній діяльності інтегрований підхід набуває все більшого поширення, оскільки завдяки йому традиційні 
уроки набувають нової форми і змісту. Учні більш схильні до стомлюваності в тій діяльності, яка сприймається ними як одноманітна, але незвичний хід уроку спонукає їх інтерес i стимулює активність, тому важливо використовувати кожну можливість гармонійного поєднання, наприклад, фізичної культури з англійською мовою. Проблема опанування викладачами фізкультури таким сучасним методом навчання, як предметна інтеграція, є актуальною і потребує уваги дослідників.

У низці робіт робиться спроба розкрити можливості інтегрованого навчання. Установлено, що інтегровані уроки фізкультури мають велику перспективу в умовах оздоровчо-освітнього закладу. Разом з учителями англійської мови розробляються плани спільних заходів, здатних зацікавити учнів, підняти престиж знань, що отримуються у школі. Застосування міжпредметної інтеграції на уроках фізкультури дозволяє підняти цю роботу на принципово новий рівень, робить її високорезультативною й ефективною, що в кінцевому підсумку і є метою освітнього процесу [5]. Указується також на необхідність проведення фізкультхвилинки на уроках англійської мови для поліпшення здоров'я школярів. Велика увага приділяється інтеграції пауз фізичної активності з вивченням англійської мови, що дозволяє не тільки підвищити фізичну активність учнів, але й більш ефективно проводити заняття в молодших класах [6]. Проведено теоретичне й експериментальне обгрунтування оптимізації процесу навчання на уроках фізичного виховання 3 учнями молодшого шкільного віку. Дослідження показали, що вік 10-11 років є сприятливим для формування рухових навичок і вмінь, а також розвитку морфофункціональних й інших здібностей учнів [3]. Фізична активність значною мірою сприяє фізичному становленню і когнітивному розвитку дітей. Зазначається, що саме на уроках фізкультури діти можуть отримати рекомендовану кількість фізичної активності [2]. Указується, що в останні роки Європейський союз збільшив попит на двомовну освіту, що знайшло відображення в навчальних законодавствах країн-членів СС через створення базису компетенції, пов'язаного 3 вивченням іноземних мов. Підкреслюється, що фізкультура в цьому проекті стала ідеальним засобом для полегшення вивчення англійської мови через гру та рухи [1]. Але проблема опанування викладачами фізкультури таким сучасним методом викладання, як інтегроване навчання, не є дослідженою до кінця.

Meта статmі полягає в обгрунтуванні доцільності проведення інтегрованих уроків фізичної культури й англійської мови і визначенні шляхів реалізації інтегрованого підходу під час організації спортивно-оздоровчих заходів чи проведенні уроку фізкультури або його фрагменту іноземною мовою (у межах дослідження - англійською).

Поглиблення міжнародного співробітництва, спрямованість України на входження до європейського співтовариства, інтернаціоналізація більшості сфер людської діяльності диктують необхідність знання іноземних мов. Зараз англійська мова $є$ основною мовою міжнародного спілкування у всіх куточках нашої планети. Знання англійської мови відіграють усе більш важливу роль у пристосуванні кожного до сучасних світових умов $\mathrm{i}$ надають величезні переваги як у повсякденному житті, так і в професійній сфері людям, які оволоділи цими знаннями. Переоцінити значення англійської мови нині, без усякого сумніву, складно. Знаючи це, вважаємо за доцільне порекомендувати встановити зв'язок фізичної культури з англійською мовою в такому поєднанні.

I. Як свідчить практика, деякі теми, що вивчаються в курсі англійської мови («Частини тіла», «Дії», «Числа», «Кольори», «Їжа», «Дім» тощо), можна поєднувати i проводити разом з уроком фізичної культури. Так, учитель ознайомлює учнів 3 новими словами, наприклад, «рука», «нога», «Голова», «обличчя», «вухо», «око», «щока», «ніс», 
«рот», «губи» тощо (тема «Частини тіла») й одночасно закріплює знання фізичними вправами. Тема «Дії» передбачає також вивчення нових слів «сідати», «вставати», «бігати», «стрибати», «ходити», «повертатися (наліво, направо)», «грати», «припиняти», «показувати» та інших, які є близькими за термінологією до уроку фізичної культури. Ці знання також можна 3 успіхом закріпити на практиці, включаючи елементи уроку англійської мови до змісту уроку фізкультури або ж навпаки.

II. Загальновідомо, що для перепочинку з учнями початкових класів потрібно проводити кілька фізкультхвилинок (зазвичай 2-3). Звичайно ж, не слід забувати, на якому уроці проводиться фізкультхвилинка і наскільки доречним буде її проведення англійською мовою. Практика свідчить, що учні молодших класів набагато швидше і краще засвоюють іншомовну лексику, вивчену за допомогою віршиків, примовок та пісеньок, поєднуючи слова $з$ діями. Наприклад.

1. Show me your shoulders (покажіть мені ваші плечі),

Show me your neck (покажіть мені вашу шию),

Clap, clap your hands (поплескали в долоні),

And show me your back (покажіть мені вашу спину).

Промовляючи разом з учителем слова примовки, діти торкаються руками відповідно плечей, шиї, плескають у долоні, повертаються спиною і знову розвертаються. Останнє слово першого рядка (shoulders) учитель змінює на інші, вже відомі дітям, назви частин тіла, закріплюючи у такий спосіб вивчену раніше лексику [4].

2. Hands on your hips (руки на стегна)!

Hands on your knees (руки на коліна)!

Put them behind you (руки перед собою), If you please (будь ласка). Touch your shoulders (доторкнулися до плечей)!

Touch your nose (доторкнулися до носа)!

Touch your ears (доторкнулися до вух)!

Touch your toes (доторкнулися до пальців ніг)!

Hands up (руки вгору)! Hands down (руки вниз)!

Hands on hips (руки на стегна) And sit down (і присіли).

3. Stand on your toes (стали навшпиньки)!

Jump: one, two, three (пострибали: раз, два, три).

Clap your hands behind (поплескали в долоні перед собою).

March slowly (маршируємо повільно) - March quickly (маршируємо швидко).

Stand up (стали)!

Turn left (повернулися наліво)!

Stand straight (стали струнко)!

Bend your head (нахилили голову)!

Stand still (стали нерухомо) [7, с. 178, 179].

III. На уроках фізкультури учні з задоволенням виконують команди, які звучать англійською мовою. Наприклад:

Fall in! (Рівняйсь!)

Attention! (Струнко!)

Good afternoon, pupils! (Добрий день, учні!)

Stand easy!/ Stand at ease!/ At ease!/ Rest! (Вільно!) Наведемо приклади вправ:

Hands up! (Підніміть руки вгору!)

Hands down! (Опустіть руки вниз!) 
Turn to the left/right! /Left (right), face! (Поверніться наліво/направо!)

About, face! (Кругом!)

Look up/ down! (Дивіться вгору/вниз!)

Close your eyes! (Закрийте очі!)

Open your eyes! (Відрийте очі!)

Mark time, march! (На місці кроком руш!)

Forward, march! (Кроком руш!)

Double time, march! (Бігом руш!)

Фізичну культуру можна ефективно й гармонійно поєднувати з уроками англійської мови. Предметна інтеграція служить засобом збагачення змісту уроку. Інтегроване навчання забезпечує формування в учнів позитивного ставлення до іноземної мови, ознайомлення їх 3 новими поняттями, перетворення мови на реальний інструмент спілкування, практичне оволодіння лексичними компетенціями на базі реальних комунікативних ситуацій, що $\epsilon$ запорукою успіху як вивчення англійської мови в цілому, так і підвищення інтересу до виконання фізичних вправ зокрема.

\section{Література}

1. Jiménez G. Educación Física en inglés. Una propuesta para trabajar la higiene postural en Educación Primaria (Physical Education in English. A proposal for working postural hygiene in Primary Education) [Електронний ресурс] /García Jiménez, García Pellicer, Yuste Lucas. Режим доступу: http://recyt.fecyt.es/index.php/retos/ article/view/34589 2. Pearson P. Recommendations for policy and practice of physical education in culturally and linguistically diverse Australian secondary schools based on a two-year prospective cohort study [Електронний pecypc]/Phil Pearson, Anthony D. Okely, Wayne G. Cotton. - Режим доступу: http://spi.sagepub.com/content/ 36/2/172.short 3. Călin R. The efficiency of using dynamic games with technical elements from handball during the Physical Education lessons with primary school pupils [Електронний ресурс] / Roman Călin. - Режим доступу: http://www.cnaa.md/en/thesis/ 4631/ 4. Зарядка или Физкультминутка на английском языке [Електронний ресурс]. - Режим доступу: http://kenglish.ru/fizkultminutka/zaryadka-ili-fizkultminutka-na-anglijskom-yazyke/ 5. Полякова Н. В. Интегрированные уроки физкультуры - возможности и перспективы [Електронний ресурс] / Н. В. Полякова // Современная педагогика. - 2014. - № 5. - Режим доступу : http://pedagogika.snauka.ru/2014/05/2349 6. Чаплинская Ю. Г. Физкультминутка на уроках английского языка в свете новых решений о повышении физической активности школьников [Электронный ресурс] / Ю. Г. Чаплинская // Современная педагогика. - 2013. № 10. - Режим доступа : http://pedagogika. snauka.ru/ 2013/10/1906 7. Цікава англійська / авт.уклад. В. Г. Куліш. - Донецьк: Сталкер, 2002. - 320 с.

\section{ОСОБЛИВОСТІ РОЗВИТКУ СУЧАСНИХ ПЕДАГОГІЧНИХ ТЕХНОЛОГІЙ}

Молчанова А. О. Особливості розвитку сучасних педагогічних технологій.

У статті розглянуті основні зміни в освітніх процесах з початку XX століття, що зумовили появу та розвиток відповідних педагогічних технологій. Наведено характеристики певних технологій, визначено основні тенденції розвитку, використання та вдосконалення сучасних педагогічних технологій у навчально-виховному процесі.

Ключові слова: навчально-виховний процес, розвиток, педагогічні технології, 